\title{
Population structure of tropical eel (Anguilla bicolor bicolor) in Cikaso River, West Java
}

\author{
Masayu Rahmia Anwar Putri ${ }^{1,2,}$, Tati Suryati Syamsudin ${ }^{1}$ \\ ${ }^{1}$ School of Life Science and Technology, Institut Teknologi Bandung, Indonesia \\ ${ }^{2}$ Research Institute for Fish Resource Enhancement, Indonesia
}

\begin{abstract}
A. bicolor bicolor is a tropical eel subspecies that dominate catches in the coastal areas of West Java, and its conservation status is near threatened. Cikaso River, West Java, becomes eel migration path, while unfortunately, information concerning the stock of eel in this river is still inadequate. The objective of this study was to determine the population structure (size distribution, length-weight relationship, and condition factor) of A. bicolor bicolor in the Cikaso River. The research was carried out in the main streams of the Cikaso River and the coastal marsh of Ciroyom from January to December 2020. Eel samples were collected using lift-net, fishhook, and traps. The number of eels caught is counted, then the total length and weight are measured. We collected nine elvers and 89 yellow eels, but no silver eel was caught during the study. The elver's total length (TL) ranged from 10.2 to $20 \mathrm{~cm}$, and the TL of yellow eel ranged from 20.1 to $42.2 \mathrm{~cm}$. The catch of eel is dominated by the size of $25-30 \mathrm{~cm}$. The growth pattern of eel in the Cikaso River is positive allometric, with the condition factor of eel ranging from 0.450 to $1.917(1.160 \pm 0.3096)$.
\end{abstract}

\section{Introduction}

Anguilla bicolor bicolor is a subspecies of tropical eel that dominated catches in the coastal areas of West Java, such as found in the Cimandiri River, Sukabumi Regency[1,2]. The conservation status of A. bicolor is currently categorized as Near Threatened [3]. One of the factors that threaten the eel population in the wild is overexploitation. According to [4], the exploitation rate of eel in the Cimandiri River estuary, especially at the glass eel stage, is $0.77 /$ year and is considered to have exceeded its optimum value $(\mathrm{E}=0.5)$. Anguilla spp. can be found in many locations in Indonesia. Besides Cimandiri River, another river in Sukabumi Regency is known to have a high potential eel resource [5] and becomes a migration path for eels [6], is located in the Cikaso River.

Unfortunately, studies conducted on the stock of eel in the Cikaso River are still inadequate. The latest research conducted by [6] found that the elver and silver eel were only found in the mainstream of the Cikaso River, and the yellow eel was only found in the estuary and Ciroyom coastal swamp. The management of eel resources requires accurate information, especially regarding the existing stock of eel. For now, there is no study

*Corresponding author: masayurahmania33@gmail.com 
conducted on the stock, especially about size distribution, length-weight relationship, and condition factors of eel in the Cikaso River.

According to [7], the length-weight relationship can be used for: stock assessment models, the estimation of biomass of a species from length-frequency distribution to an estimation of the condition of the fish, and for life history and morphological comparisons of certain populations from different regions. This study aimed to determine the stock (size distribution, length-weight relationship, and condition factor) A. bicolor bicolor in the Cikaso River system, especially in the young to adult stages. The study results are expected to contribute to the eel management for their sustainability.

\section{Methods}

This research was carried out in the mainstream of the Cikaso River (Station 1-12) and coastal marsh of Ciroyom (Station 13-18) from January to December 2020 (Figure 1). Location grouping is based on different habitat characteristics, where stations 1 to 12 are located in the main flow of the Cikaso River, which is identical to the strong water current, deeper waters, and low salinity levels. Stations 13-18 are located in coastal swamps with a weak water current, relatively shallow water, and higher salinity than the main flow of the Cikaso River [8].

The eel life cycle itself can be divided into several stages: leptocephalus, glass eel, elver, yellow eel, and silver eel [9]. The stages of eels that have migrated to fresh water and have a body shape like the adult eels are in the elver, yellow eel, and silver eel stages. Anguilla bicolor species in these three stages are relatively easy to identify. It is known as a shortfin eel due to a short dorsal fin and the dorsal origin above the anus. It also has plain body skin [10]. The eel stage in this study was classified based on [11] and [12] studies. Tesch [11] classified an elver stage as the eel with a length greater than $7 \mathrm{~cm},[12]$ grouped the yellow eel stage as the eel with a length of 20-45 cm, and eels with a size greater than $45 \mathrm{~cm}$ are in the adult/silver eel stage [13].

\subsection{Eels collection}

Eel samples were collected using lift net "sirib", traps "bubu", and fishhooks "teger". Eels collection is carried out every month from January to December 2020, during the new moon period. The traps and fishhooks are placed in research stations around 06.00-08.00 pm and are discharged at around 07.00-09.00 am the next day. Besides the two types of fishing gear, eels are also collected from the by-catch of "sirib" / lift net. Fishers operated lift net between three stations: stations 1,3 , or 12 . Fishhooks are placed at stations 1 to 11 , while traps are placed at stations 1, 2, 7, 10, and 11 (representing the main channel of the Cikaso River), and stations 13 to 18 (representing coastal marsh of Ciroyom). We grouped it into four zones; Stations 1 to 6 represented the upstream area, stations 7 to 10 represented the middle area of Cikaso River, stations 11 and 12 represented the coastal area, and stations 13 to 18 coastal marsh of Ciroyom.

Eel samples were identified using [10], then the total length $(\mathrm{cm})$ and weight (grams) were measured. Fish length measurements with an accuracy of $0.1 \mathrm{~cm}$ and their body weight were weighed using a digital scale with an accuracy of 0.01 grams. 


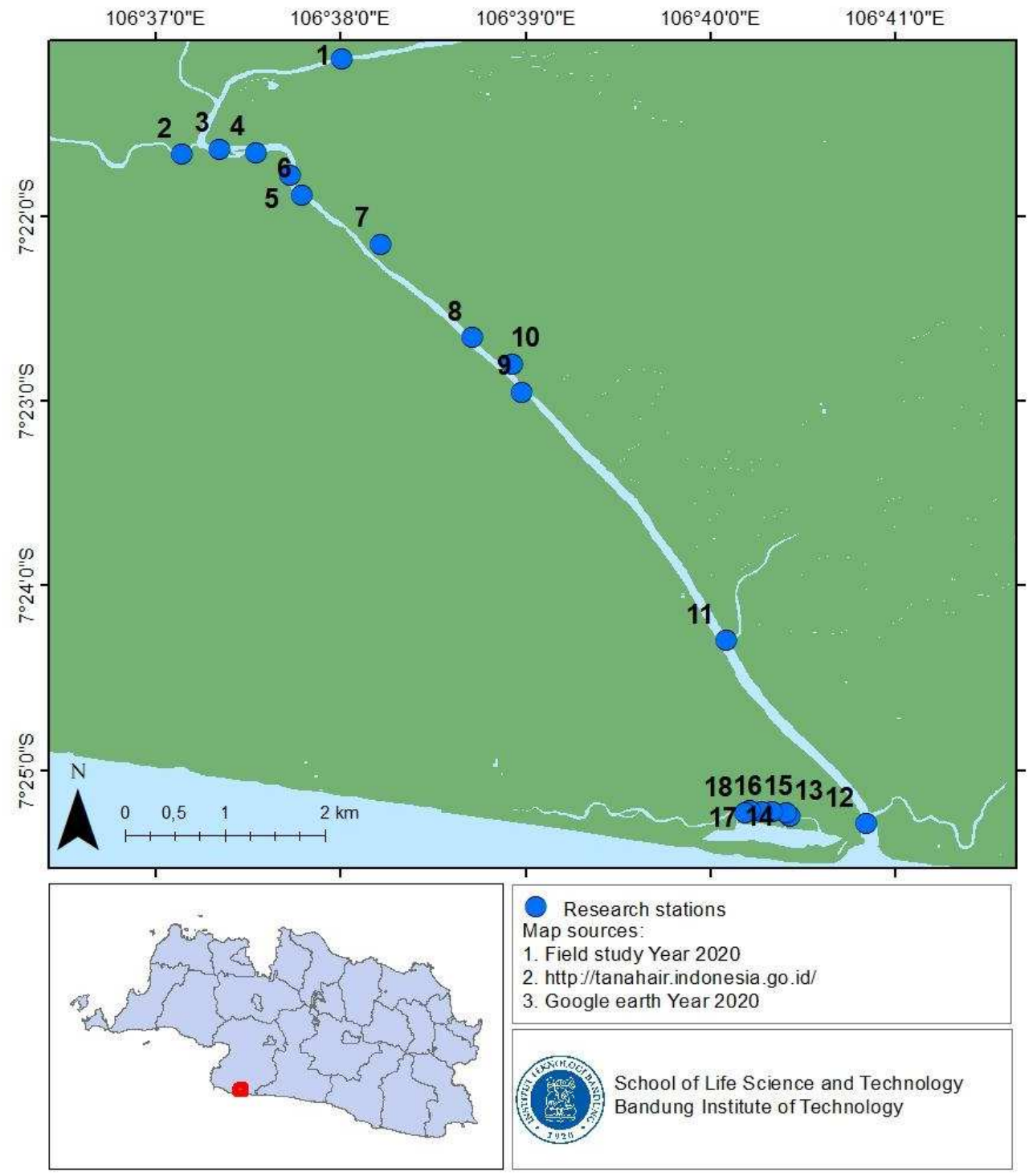

Fig. 1. Research locations in the Cikaso River

\subsection{Data analysis}

The length-weight relationship of the eel is calculated using the formula:

$$
W=a L^{b}
$$

Where "W" is the weight of fish (g), "L" is the total length of fish $(\mathrm{cm})$, "a" and "b" are constants. The value of $b$ is used to predict the growth pattern. When the value of $b$ is equal to 3 , it indicates an isometric growth pattern, and when its value is other than 3 , it shows an allometric growth pattern. If the $b$ value is greater than 3 , it shows that the eel has a positive allometric growth pattern (faster weight growth), and if the b value is less than 3 , it shows that the eel has a negative allometric growth pattern (faster length growth)). The conclusion 
of the $b$ value obtained was determined by performing a t-test at a $95 \%$ confidence interval $(\alpha=0.05)$ [14].

The condition factor is analyzed to determine the condition or health of the fish based on the length and weight data. The condition factor value $(\mathrm{K})$ is calculated by the following formula [14]:

$$
K=\frac{W}{a L^{b}}
$$

Where " $\mathrm{K}$ " is the condition factor, " $\mathrm{W}$ " is eel's weight in grams, " $\mathrm{L}$ " is eel's length in $\mathrm{cm}$, "a" and "b" are regression constants of the length-weight relationship.

Statistical analysis in this study used the PAST 4.01 program and the data analysis package in Microsoft Excel.

\section{Results}

\subsection{Size distribution}

Ninety-eight Anguilla bicolor bicolor was found during the research, consisting of nine elvers stage and 89 yellow eels. Except for the middle area (stations 7 to 10), eels caught in the upstream (stations 1 and 4), coastal (station 11), and coastal marsh (stations 13 to 18). The elver stadium (size class 10 to $20 \mathrm{~cm}$ ) and yellow eel (size class 20 to $45 \mathrm{~cm}$ ) can be found in the upstream and the coastal marsh, while in the coastal zone, we only found yellow eel stadium (Figure 2). The elver ranged from 10.2 to $20 \mathrm{~cm}$, and those caught were dominated by 15 to $20 \mathrm{~cm}$. The yellow eel was caught at 20.1 to $42.2 \mathrm{~cm}$, and the dominant size ranged from 25 to $30 \mathrm{~cm}$. Most of A. bicolor bicolor eels were found at 25 to $30 \mathrm{~cm}$ TL by $30 \%$ (29 individuals), while the eels with TL 10 to $15 \mathrm{~cm}$ and 40 to $45 \mathrm{~cm}$ were caught the least, only $3 \%$, and $1 \%$, respectively. Yellow eel dominated about $91 \%$ of the total eel caught. The length class distribution of $A$. bicolor bicolor caught during the study is shown in Figure 3.

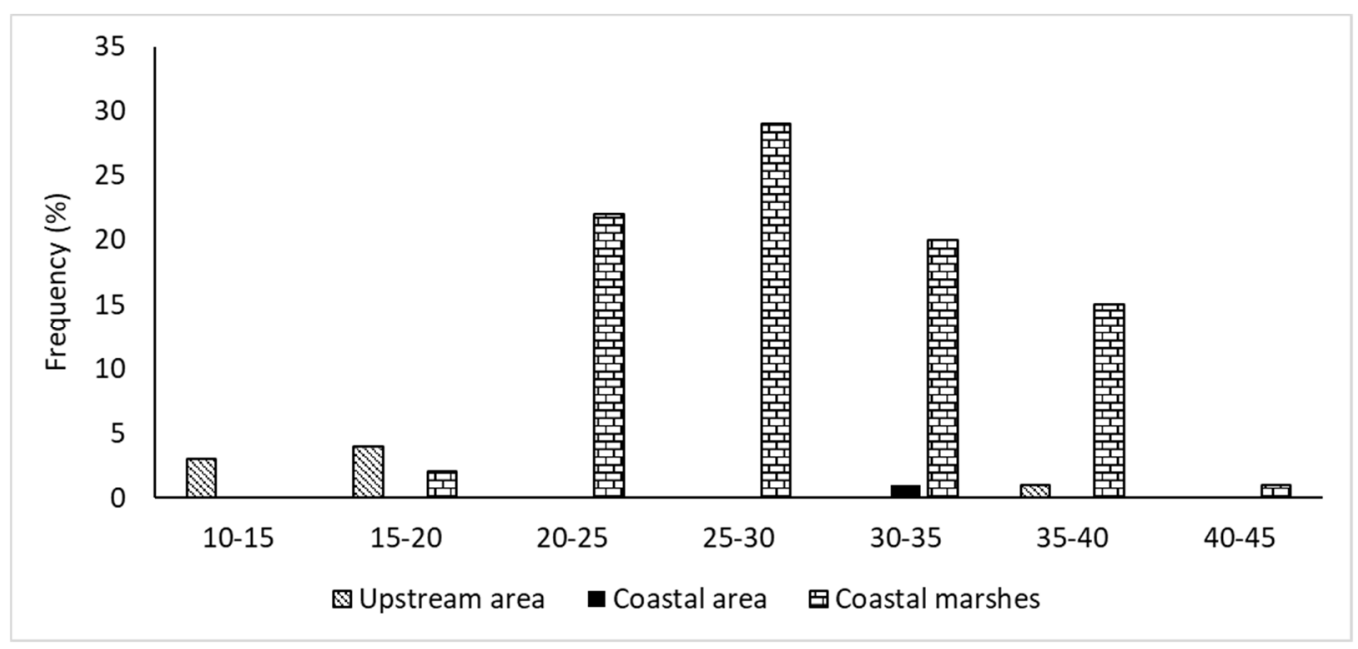

Fig. 2. Eel's size distribution, based on three zones; upstream area, coastal area, and coastal marsh. 


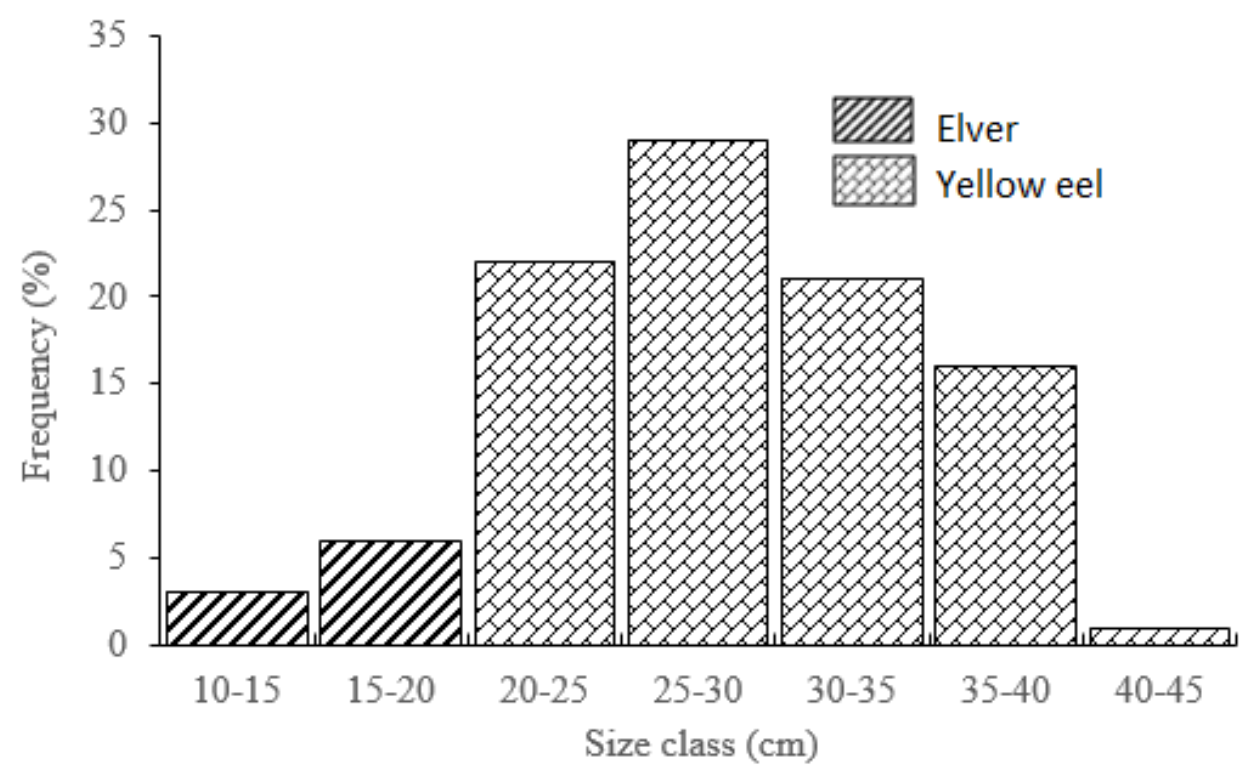

Fig. 3. Distribution of length class ( $(\mathrm{cm})$ of Anguilla bicolor bicolor $(\mathrm{n}=98)$

\subsection{The length-weight relationship of Anguilla bicolor bicolor}

The length-weight relationship graphs of Anguilla bicolor bicolor without sex differentiating for the upstream and coastal marsh areas are shown in Figures 4 and 5, respectively. The ttest of the value $b$ at $95 \%$ significance level against the value 3 for eels in the upstream area obtained $t_{\text {count }}(8.69)>t_{\text {table }}(1.99)$ and for coastal marsh $t_{\text {count }}(3.34)>t_{\text {table }}$ (2.45). The $p-$ value for both areas is smaller than 0.05 , which means rejecting hypothesis $\mathrm{HO}(b \neq 3)$, so it concluded that the eels upstream of the Cikaso River and coastal marsh of Ciroyom have a positive allometric growth pattern (weight gain is faster than length increase).

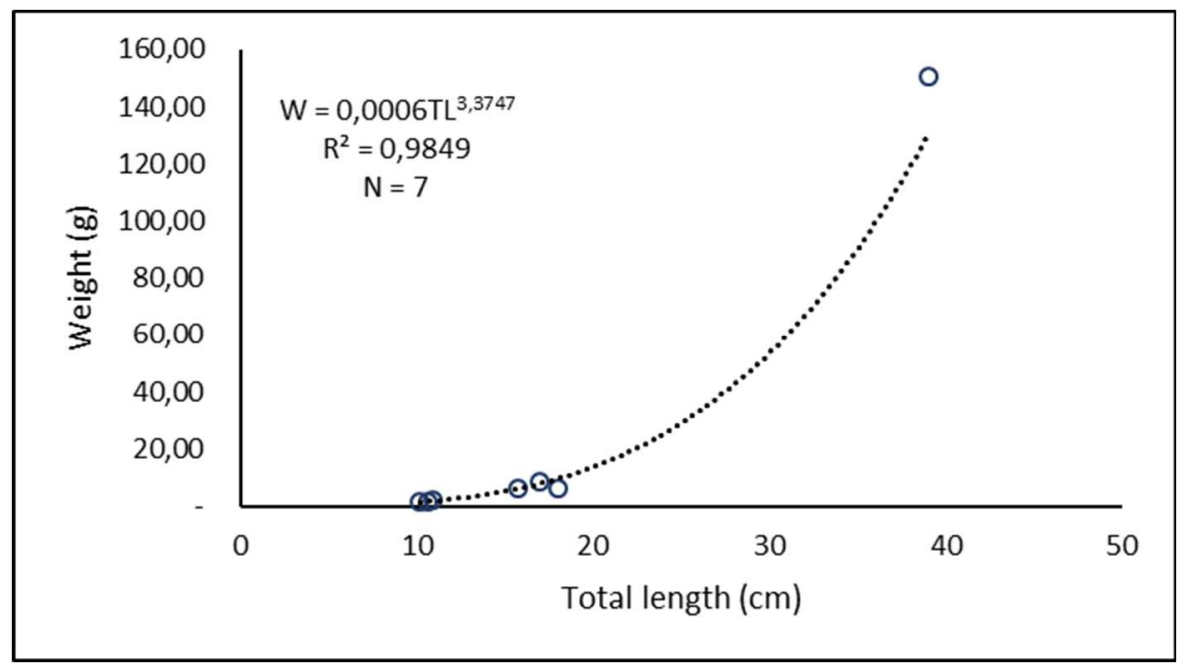


Fig. 4. Length-weight relationship of A. bicolor bicolor in upstream area the Cikaso River

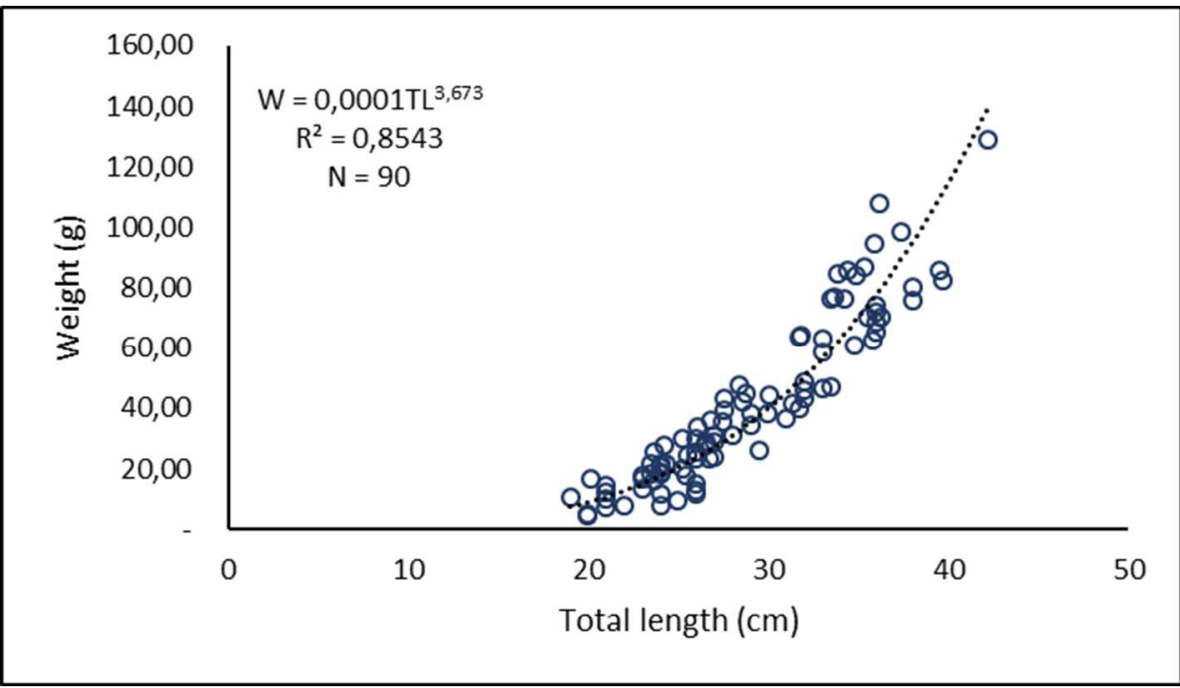

Fig. 5. Length-weight relationship of A. bicolor bicolor in the coastal marsh of Ciroyom

\subsection{The condition factors of Anguilla bicolor bicolor}

The condition factor of $A$ bicolor bicolor in the Cikaso River ranged from 0.450-1.917, with an average of $1.160 \pm 0.3096$. The size difference of the eel did not affect the condition factor of the eel caught during the study. This result was proven by using the Kruskal-Wallis test, which showed no significant difference between the median values of each eel size group (by excluding the $40-45 \mathrm{~cm}$ size class) (p-value $0.1911>0.05$ ) (Table 1). Table 2 shows the difference of condition factor $(\mathrm{Kn})$ from three zones in the study site. The value of eel's condition factor from upstream and coastal area is higher than eel's condition factor from the coastal marsh.

Table 1. The value of condition factor $(\mathrm{Kn})$ of eel (A. bicolor bicolor) based on length $(\mathrm{cm})$

\begin{tabular}{|c|c|c|ccc|}
\hline Life stage & Size class $(\mathrm{cm})$ & Kn Range & \multicolumn{3}{|c|}{ Kn average } \\
\hline \multirow{3}{*}{ Elver } & $10-15$ & $1.460-1.644$ & 1.561 & \pm & 0.093 \\
\cline { 2 - 6 } & $15-20$ & $0.508-1.601$ & 1.0667 & \pm & 0.4749 \\
\hline \multirow{3}{*}{ Yellow eel } & $20-25$ & $0.450-1.768$ & 1.0816 & \pm & 0.3483 \\
\cline { 2 - 6 } & $25-30$ & $0.524-1.586$ & 1.1455 & \pm & 0.2866 \\
\cline { 2 - 6 } & $30-35$ & $0.897-1.917$ & 1.235 & \pm & 0.2778 \\
\cline { 2 - 6 } & $35-40$ & $0.890-1.726$ & 1.1578 & \pm & 0.2541 \\
\cline { 2 - 6 } & $40-45$ & 1.135 & & & \\
\hline
\end{tabular}

Table 2. The value of eel's condition factor $(\mathrm{Kn})$ based on zonation

\begin{tabular}{|c|c|c|ccr|}
\hline Zone & Totals (individuals) & Kn Range & \multicolumn{3}{|c|}{ Kn average } \\
\hline Upstream area & 7 & $0.961-1.644$ & 1.447 & \pm & 0.2528 \\
\hline Coastal area & 1 & 1.912 & & & \\
\hline Coastal marsh & 90 & $0.45-1.767$ & 1.126 & \pm & 0.2902 \\
\hline
\end{tabular}

\section{Discussion}


All eels caught in the Cikaso River during the study were in the early stage. The average total length of elver and yellow eel caught in the present study $(25.9 \pm 8.36 \mathrm{~cm})$ was not much different from eels found in the Cimandiri River in 2018 with a size of $25.5 \pm 5.4 \mathrm{~cm}$ [4]. The size of eels found in the Cimandiri River in 2015 was relatively smaller, ranging from 6.2 $26.1 \mathrm{~cm}(12.25 \pm 4.01 \mathrm{~cm})$ [1]. The research results [6] in the Cikaso River found eels at the adult stage for subspecies $A$. bicolor bicolor with a total length of $63 \mathrm{~cm}$.

The length-weight relationship and condition factor could describe the condition of the eel population in nature. The positive allometric growth pattern of eels obtained at the study site is identical to the results of research conducted by [15-17]. It is different from [18], which showed isometric growth patterns in eels, and research conducted by [4], which showed negative allometric growth patterns. Differences in growth patterns occurred because of the influence of environmental conditions, maturity, season, sex, food availability, stomach fullness, health, preservation techniques, and differences of length ranges of the specimen caught $[7,15,19]$. The Cikaso River and the coastal marsh of Ciroyom are the habitats preferred by eels based on environmental variables such as salinity, turbidity, dissolved oxygen, conductivity, total dissolved solids, water current, water depth, and occurrence of vegetation, and bottom substrate. The availability of food for eels is associated with the occurrence of vegetation in both zones. Insects become the main food for eels feed when small, and crabs become the main food as they grow [8].

The condition factor represented the quality of the eel based on the comparison of the actual weight to the estimated weight [4]. The condition factor of eels in the upstream (1.447 $\pm 0.2528)$ and the coastal area (1.912) is relatively higher than the coastal marsh area $(1.126$ $\pm 0.2902)$. The eels from upstream consisted of elver stage, while from coastal marsh dominated by yellow eel stage. In other species, like white grouper (Epinephelus aeneus), the condition factor usually decreases as the fish increases in size [20]. Nevertheless, our analysis showed no significant difference between the eel size group based on the condition factor value (Table 1).

Figure 6 shows a comparison of the condition factors $(\mathrm{Kn})$ of eel in several research locations. Locations 1 and 2 are located on the Cikaso River, which is the location for primary data collection: the main channel of the Cikaso River and coastal marsh of Ciroyom. The condition factor at location 3 (Cimandiri River) was obtained from research results [4], Kn at location 4 (Segara Anakan Waters) from research [21], and Kn at location 5 in southern Sri Lanka from [22]. The average Kn of eels in the mainstream of the Cikaso River was higher than in other areas.

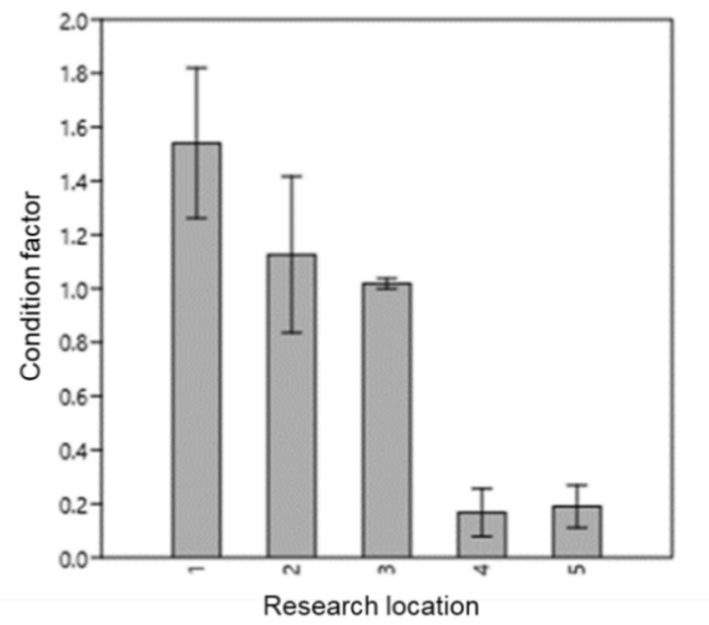

\begin{tabular}{cl}
\hline Code & Research Locations \\
\hline 1 & Main flow of Cikaso River \\
2 & Coastal marsh of Ciroyom \\
3 & Cimandiri River, West Java \\
4 & Segara Anakan, Cenral Java \\
5 & Southern Srilanka \\
\hline
\end{tabular}


Fig. 6. Condition factors of A. bicolor bicolor in several areas (black lines indicate significant differences between locations)

According to [4], the condition of the eel is influenced by food availability and environmental conditions. The high Kn values of eel found in the Cikaso River and Cimandiri River indicated that this area provides sufficient food and has better ecological conditions for eel growth compared to the waters of Segara Anakan and Southern Sri Lanka. Cimandiri waters are in excellent condition based on their water quality index [4]. Besides, the water environmental parameters of Cikaso River and coastal marsh of Ciroyom are preferred by eels and food sources available for eels with the vegetation cover [8]. A decrease in environmental conditions occurs in Segara Anakan. Extensive mangrove area decreased in this area over the previous year [23][23,24]. The size of the Segara Anakan lagoon has also reduced due to high sedimentation from Citanduy River [25]. The metal content in these waters also exceeded the water quality standard for fisheries [26,27].

\section{Conclusion}

Nine elvers and 89 yellow eels of Anguilla bicolor bicolor caught at the research site. The elver stage's total length (TL) ranged from 10.2 to $20 \mathrm{~cm}$, and the TL of yellow eel ranged from 20.1 to $42.2 \mathrm{~cm}$. Eels dominated the catch with TL $25-30 \mathrm{~cm}$ (yellow eel stage). The growth pattern of eel in the Cikaso River system (The mainstream of Cikaso River and coastal marsh of Ciroyom) is positive allometric, with the condition factor of eel ranging from 0.450 to $1.917(1.160 \pm 0.3096)$.

\section{Acknowledgement}

The authors would like to thank the Indonesia Endowment Fund for Education (LPDP) for funding this research.

\section{References}

1. A. A. Hakim, Master thesis, Bogor (ID): IPB University (2015)

2. Triyanto, R. Affandi, M. M. Kamal, G. S. Haryani (in Bahasa Indonesia), J. Ilmu dan Teknol. Kelaut. Trop. 11, 2 (2019)

3. IUCN Red List of Threatened Species. C. Pike, V. Crook, D. Jacoby, M. Gollock, www.iucnredlist.com (IUCN Red List, 2020)

4. Triyanto, Ph.D Thesis, Bogor (ID): IPB University (2020)

5. H. Haryono, G. Wahyudewantoro, Omni-Akuatika 12, 3 (2016)

6. Y. Sugianti, M. R. A. Putri, S. Purnamaningtyas (in Bahasa Indonesia), Limnotek Perair. Darat Trop. di Indones. 27, 1 (2020)

7. S. Kuriakose, Course Manual Summer School Advanced Methods Fish Stock Assessment Fish Management Lecture Note Series (2017)

8. M. R. A. Putri, Master Thesis. Bandung (ID): Institut Teknologi Bandung (2021)

9. A. Cresci, C. M. Durif, C. B. Paris, S. D. Shema, A. B. Skiftesvik, H. I. Browman, Commun. Biol. 2, 1-8 (2019)

10. M. Kottelat, A. J. Whitten, S. N. Kartikasari, S. Wiroatmodjo, Freshwater Fishes of Western Indonesia and Sulawesi (Periplus Edition, Singapore, 1993)

11. F. W. Tesch, The Eel (Blackwell Science Ltd, a Blackwell Publishing Compan, 2003) 
12. F. Rachmawati, Y. Sistina, IOP Conf. Ser. Earth and Environ. Sci. 593 (2020)

13. I. J. Chai, T. Arai, J. Appl. Anim. Res. 46, 1 (2017)

14. A. L. Godinho, Environ. Biol. Fishes 50, 319 (1997)

15. N. K. Suryati, Fauziyah, Ngudiantoro, J. Environ. Sustain. Manag, 2, 2 (2018)

16. M. F. Ismail, M. N. A. Amal, S. Shohaimi, A. Ismail, S. Z. Zulkifli, N. I. A. Ghani, Trop. Nat. Hist. 17, 1 (2017)

17. M. Sidqi, M. A. Sarong, A. S. Batubara, Z. A. Muchlisin, IOP Conf. Ser. Earth and Environ. Sci. 216, (2018)

18. Kardin, L. Sara, U. K. Pangerang (in Bahasa Indonesia), J. Manaj. Sumber Daya Perair. 1, 4 (2016)

19. R. Froese, J. Appl. Ichthyol. 22, 4 (2006)

20. W. Ndiaye, K. Diouf, O. Samba, P. Ndiaye, J. Panfili, Int. J. Adv. Res. 3, 3 (2015)

21. I. Herianti and D. Nugroho (in Bahasa Indonesia), BAWAL 3, 3 (2010)

22. P. Cumaranatunga, A. Ranawickreme, H. Wickstrom, K. Vithanage, Asian Fish. Sci. 10, 1 (1997)

23. A. Nurfiarini, L. Adrianto, S. Budi, M. M. Kamal, Int. J. Sci. Basic Appl. Res. 19, 1 (2015)

24. A. D. Purwanto, Master Thesis. Depok (ID): Universitas Indonesia (2017)

25. R. Dewi, M. Zainuri, S. Anggoro, T. Winanto, Omni-Akuatika 12, 3(2016)

26. A. F. Kasari, H. Effendi (in Bahasa Indonesia), Pros. Semin. Nas. Ikan Ke-9 421-432 (2016)

27. Hartono, A. S. Siregar, N. V. Hidayati, Omni-Akuatika 7, 16 (2013) 